\title{
Pengaruh Penempatan, Beban Kerja dan Motivasi Kerja Terhadap Kinerja Pegawai Pada Polrestabes Palembang
}

\author{
Muhammad Kurniawan ${ }^{1}$, Benny Usman'2, Joni Iswan', Suci Novia Rahmadani ${ }^{4}$ \\ ${ }^{1}$ Fakultas Ekonomi dan Bisnis Universitas PGRI Palembang, iwanusman220516@gmail.com \\ ${ }^{2}$ Fakultas Ekonomi dan Bisnis Universitas PGRI Palembang, broperlengkapan@gmail.com \\ ${ }^{3}$ Fakultas Saint dan Teknologi Universitas PGRI Palembang, joni.iswan@gmail.com \\ ${ }^{4}$ Fakultas Ekonomi dan Bisnis Universitas PGRI Palembang, srahmadani181199@gmail.com
}

\begin{abstract}
ABSTRAK
Penelitian ini bertujuan untuk mengetahui Pengaruh Penempatan, Beban Kerja dan Motivasi Kerja terhadap Kinerja Pegawai Pada Polrestabes Palembang. Populasi dalam penelitian ini adalah 57 pegawai yang merupakan pegawai di bagian sumda pada Polrestabes Palembang. Sampel pada penelitian ini menggunakan metode dengan rumus sampling jenuh dengan pegawai berjumlah 57 orang. Metode pengumpulan data dilakukan dengan menggunakan kuesioner. Teknik analisis data yang digunakan adalah analisis regresi linear sederhana, analisis regresi linear berganda,koefisien korelasi, koefisien determinasi, uji T dan uji $\mathrm{F}$ dengan menggunakan program SPSS For Windows versi 23. Hasil pengujian hipotesis uji t secara parsial antara variabel Penempatan terhadap Kinerja Pegawai diperoleh nilai sig 0,000 $<0,05$. Maka disimpulkan ada pengaruh yang signifikan antara Penempatan terhadap Kinerja Pegawai. Hasil uji t untuk variabel Beban Kerja terhadap Kinerja Pegawai diperoleh nilai sig 0,001 $<0,05$. Maka dapat disimpulkan ada pengaruh yang signifikan antara variabel Beban Kerja terhadap Kinerja Pegawai. Hasil uji t untuk variabel Motivasi Kerja Terhadap Kinerja Pegawai diperoleh nilai sig 0,000 <0,05, maka dapat disimpulkan ada pengaruh yang signifikan antara variabel Motivasi Kerja terhadap Kinerja Pegawai pada Polrestabes Palembang. Sedangkan hasil Penelitian uji $\mathrm{F}$ untuk variabel Penempatan, Beban Kerja dan Motivasi Kerja terhadap Kinerja Pegawai diperoleh nilai sig 0,000 $<0,05$ maka menunjukkan ada pengaruh yang signifikan antara Penempatan, Beban Kerja dan Motivasi Kerja secara bersama-sama terhadap Kinerja Pegawai pada Polrestabes Palembang.
\end{abstract}

Kata Kunci : Penempatan, Beban Kerja, Motivasi Kerja dan Kinerja Pegawai.

\begin{abstract}
This study aims to determine the effect of placement, workload and work motivation on employee pervomance in Polrestabes Palembang. Population in this study is 57 employee who is an employee in the sumda section of Polrestabes Palembang. the sample in this study used the saturated sampling jenuh method with employees amounting to 57 person. Method of data collection is done by using a questionnaire. Technical analysis of the data used is simple linear regression analysis, multiple linear regression analysis, correlation coefficient, coefficient of determination, uji $t$ and uji $f$ by using the program for windows versi 23 . Results testing hypothesis uji t partially between the placement variable and employee performance, the value of sig $0,000<0,05$. It is concluded that there is a significant influence between placement on employee performance. This uji $t$ for the workload variable on employee performance, the value of is obtained sig 0,001<0,05. It is concluded that there is a significant effect between the workload variable on employee performance. This uji $t$ for the work motivation variable on employee performance, the value of is obtained sig $0,000<0,05$, it can be concluded that there is a significant influence between work motivation variable on employee performance. While the research results uji $f$ for the variable of placement, workload and work motivation on employee performance, the value of is obtained sig 0,000<0,05 it shows that there is a significant influence between the variable of placement, workload and work motivation together on employee performance at Polrestabes Palembang.
\end{abstract}

Keywords : placement, workload, work motivation and employee performance 


\section{A. PENDAHULUAN}

Suparyadi (2015 : 3), Sumber Daya Manusia merupakan suatu sistem yang bertujuan untuk mempengaruhi sikap, perilaku, dan kinerja karyawan agar mampu memberikan kontribusi yang optimal dalam rangka mencapai sasaran-sasaran perusahaan. Karena manajemen sumber daya manusia bisa meningkatkan kinerja perusahaan karena kinerja karyawan akan membekali mereka untuk kepentingan melaksanakan pekerjaan pada masa yang akan datang. Sumber Daya Manusia itu diperhatikan secara tepat dengan menghargai bakat dan keahlian mereka, mengembangkan kemampuan mereka dan mendayagunakan secara tepat, maka suatu organisasi akan dapat bergerak secara dinamis dan berkembang dengan pesat.

Berdasarkan undang-undang nomor 2 tahun 2002 tentang Kepolisian Negara Republik Indonesia, pasal 5, menyebutkan bahwa kepolisian merupakan alat Negara yang berperan dalam memelihara keamanan dan ketertiban masyarakat, menegakkan hukum serta memberikan perlindungan, pengayoman dan pelayanan kepada masyarakat dalam rangka terpeliharanya keamanan dalam negeri. Polres/polresta/polrestabes adalah struktur komando kepolisian republik Indonesia didaerah kabupaten/kota kepolisian resort diwilaya perkotaan biasa disebut kepolisian resort kota besar (polrestabes). Peningktakan pelayanan baik keamanan dan administrasi selain itu kenaikan tipe ini akan meningkatkan kinerja polrestabes Palembang dalam mengayomi dan melayani masyarakat.

Tohardi (2016 : 125), penempatan merupakan menempatkan pegawai pada pekerjaan yang sesuai dengan keterampilan atau pengetahuannya dan proses mengetahui karakter atau syarat-syarat yang diperlukan untuk mengerjakan suatu pekerjaan tugas.

Penempatan juga bisa menjadi permasalahan tersendiri bagi pegawai di Polrestabes wilayah Palembang, terdapat penghambatan dan sering terjadi masalah tentang penempatan dan banyak pegawai yang bekerja tidak sesuai dengan kemampuannya.

Ahmad Hannani (2016 : 4), beban kerja merupakan sesuatu yang muncul dari interaksi antara tuntutan tugas lingkungan kerja dimana digunakan sebagai teman kerja keterampilan, perilaku, dan persepsi dari pekerja.

Beban kerja juga bisa menjadi permasalahan tersendiri bagi pegawai di Polrestabes wilayah Palembang yaitu permasalahan pada lapangan kerja dengan masyarakat yang membutuhkan energi dan waktu yang panjang, serta pembuatan surat atau dokumen yang harus membutuhkan waktu yang panjang untuk menyelesaikannya.

Malayu Hasibuan (2015 : 110), motivasi kerja merupakan kondisi atau energy yang menggerakkan diri karyawan yang terarah atau tertuju untuk mencapai tujuan organisasi perusahaan yang menciptakan ke gairahan kerja seseorang, agar mereka mau bekerja sama, bekerja efektif dan terintegrasi dengan segala daya upayanya untuk mencapai kepuasan.

Motivasi Kerja juga bisa menjadi permasalahan tersendiri bagi pegawai di Polrestabes wilayah Palembang yaitu persaingan antara pegawai dalam melakukan pekerjaan dan dalam setiap pekerjaan itu kita harus memiliki semangat untuk bekerja atau dorongan dari dalam diri pegawai.

Sinambela (2017: 480), kinerja pegawai adalah hasil atau tingkat keberhasilan seseorang atau keseluruhan selama periode tertentu dalam melaksanakan tugas 
dibandingkan dengan berbagai kemungkinan seperti standard hasil kerja, target atau sasaran kriteria yang telah ditentukan terlebih dahulu dan telah disepakati bersama.

Kinerja pegawai juga bisa menjadi permasalahan tersendiri bagi pegawai di Polrestabes wilayah Palembang yaitu adanya pekerjaan yang tidak sesuai dengan perannya dan kurangnya pelatihan kepada pegawai yang tidak memadai, kurangnya disiplin kerja kepada pegawai dan banyaknya pegawai yang terlambat karena banyak pegawai yang datang tidak sesuai dengan jam kerja.

\section{B. KAJIAN TEORI}

\section{Penempatan}

Mondy (2015 : 153), menjelaskan bahwa penempatan pada saat itu seseorang calon karyawan dinyatakan diterima dan siap untuk ditempatkan pada jabatan atau unit kerja yang sesuai dengan kualitasnya. Penempatan bukanlah bersifat final melainkan harus tetap terbuka kesempatan untuk pemindahannya.

Dari pengertian menurut para ahli diatas, penempatan adalah merupakan seleksi karyawan karena sebelum karyawan ditempatkan pada posisi itu harus diseleksi dulu, untuk menempatkan posisi karyawan tersebut harus sesuai dengan kemampuannya.

\section{Beban Kerja}

Tarwaka (2017 : 106),Beban Kerja adalah suatu kondisi dari pekerjaan dengan uraian tugasnya harus diselesaikan pada tepat waktu. Sejumlah kegiatan yang harus diselesaikan oleh organisasi atau pemegang jabatan secara sistematis.

Dari pengertian menurut para ahli diatas, Beban Kerja adalah merupakan suatu pekerjaan yang akan diselesaikan tepat waktu dan yang dirasakan berada diluar kemampuan pekerja, sejumlah kegiatan dilingkungan kerja yang membuat karyawan semakin tertekan dengan pekerjaannya, dan merupakan suatu unit organisasi atau pemegang jabatan dalam jangka waktu tertentu.

\section{Motivasi Kerja}

Muhammad Busro (2018:50), motivasi kerja merupakan sebagai proses yang menjelaskan intensitas, arah, dan ketekunan seorang individu untuk mencapai tujuan, kemauan untuk menggunakan usaha tingkat tinggi untuk tujuan organisasi. Dilihat dari pengertian menurut para ahli diatas, bahwa Motivasi Kerja adalah suatu proses yang mencapai tujuan untuk usaha tingkat tinggi dalam suatu organisasi dan bisa memotivasi pegawai tetapi motivasi itu sendiri mencerminkan reaksi individu terhadap stimula tersebut, motivasi merupakan sebagai dorongan dalam menjalankan pekerjaannya.

\section{Kinerja Pegawai}

Wibowo (2014 : 7), Kinerja pegawai merupakan serangkaian aktivitas yang dilakukan untuk memastikan bahwa suatu evaluasi kinerja dalam organisasi tertentu dapat mencapai tujuan sesuai dengan kebutuhan organisasi. Pekerjaan dan hasil yang dicapai dari pekerjaan tersebut, mempunyai masa yang lebih luas bukan hanya hasil kerja, tetapi termasuk bagaimana proses pekerjaan berlangsung. Dan tentang apa yang dikerjakandanbagaimanacaramengerjakannya.

Dari definisi menurut para ahli diatas bahwa, Kinerja pegawai adalah bahwa suatu organisasi suatu profesi kualitas dan kuantitas yang dimiliki oleh individu yang berbeda untuk berkontribusi dan mencapai tujuan, visi dan misi pada suatu instansi 
dan hasil yang telah di capai sesorang dari tingkah kerjanya dalam melaksanakan aktivitasnya.

\section{Kerangka Pemikiran}

Sugiyono (2018 : 128), merupakan model konseptual tentang bagaimana teori hubungan dengan berbagai faktor yang diindentifikasi sebab masalah yang penting.

Kerangka pemikiran dalam penelitian ini adalah Penempatan $\left(\mathrm{X}_{1}\right)$, Beban $\operatorname{Kerja}\left(\mathrm{X}_{2}\right)$ Dan Motivasi $\operatorname{Kerja}\left(\mathrm{X}_{3}\right)$, sebagai variabel bebas dan Kinerja Pegawai $(\mathrm{Y})$ sebagai terikat.

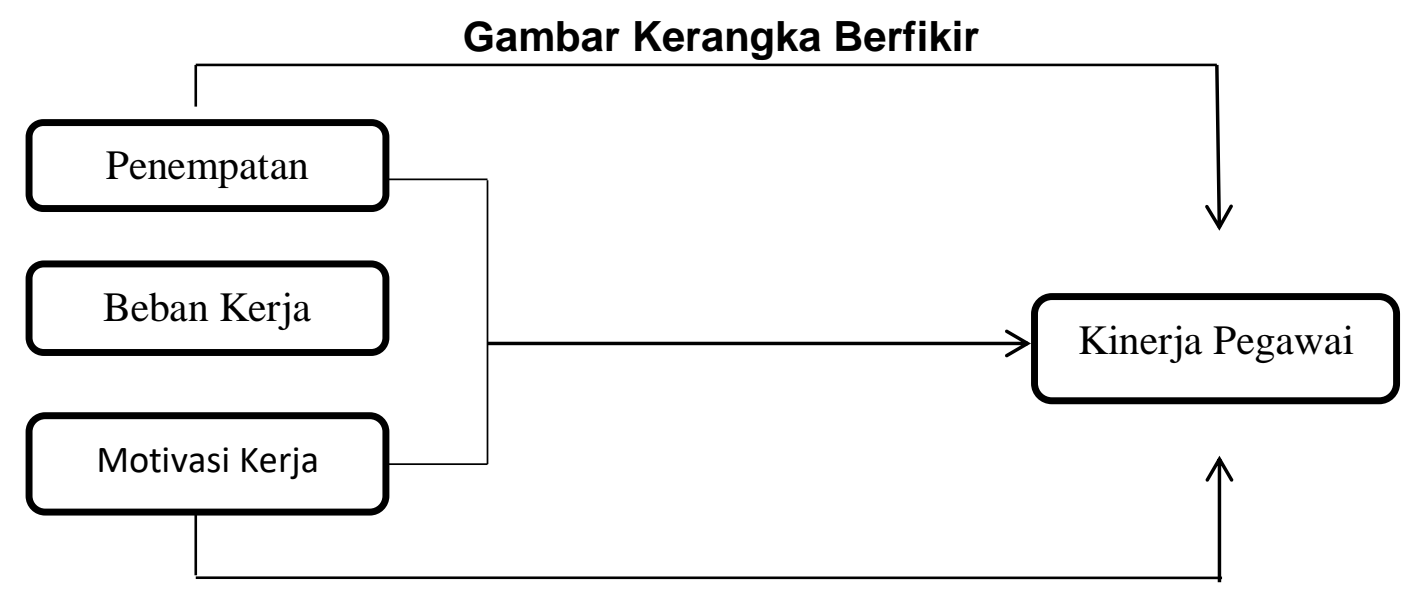

\section{Hipotesis Penelitian}

Sugiyono (2018:134), bahwa hipotesis merupakan jawaban sementara terhadap rumusan masalah penelitian, dimana rumusan masalah penelitian telah dinyatakan dalam bentuk kalimat pertanyaan. Dikatakan sementara, karena jawaban yang diberikan baru didasarkan pada teori yang relevan, belum ada bukti-bukti yang sesuai dengan pengamatan. Dalam kaitannya dengan penempatan, beban kerja dan motivasi kerja terhadap kinerja pegawai. Maka peneliti menyimpulkan dugaan sementara dalam penelitian ini yaitu:

$\mathrm{H}_{1}$ : Penempatan, ada pengaruh signifikan terhadap kinerja pegawai polrestabes Palembang.

$\mathrm{H}_{2}$ : Beban kerja, pengaruh signifikan terhadap kinerja pegawai polrestabes Palembang

$\mathrm{H}_{3}$ : Motivasi kerja, pengaruh signifikan terhadap kinerja pegawai polrestabes Palembang

$\mathrm{H}_{4}$ : Penempatan, beban kerja dan motivasi kerja, secara bersama-sama berpengaruh signifikan terhadap kinerja pegawai.

\section{METODE PENELITIAN}

1. Objek Penelitian

Yang menjadi objek penelitian ini adalah seluruh pegawai polri pada Polrestabes Palembang, yang berlokasih di Jln. Gub. H. Ahmad Bastari 01 Palembang 30252 sumatera selatan. 


\section{Variabel Penelitian}

Sugiyono (2018 : 95), mengemukakan bahwa variabel penelitian pada dasarnya merupakan segala sesuatu yang berbentuk objek atau kegiatan yang bermacammacam yang ditetapkan oleh peneliti untuk dipelajari dan kemudian ditarik kesimpulannya. Didalam penelitian ini, variabel yang digunakan adalah sebagai berikut :

$>$ Variabel bebas (independen variabel), ialah variabel yang mempengaruhi atau yang menjadi sebab perubahannya. Variabel bebas $(X)$ dalam penelitian ini terdiri dari penempatan $\left(X_{1}\right)$, beban kerja $\left(X_{2}\right)$ dan motivasi kerja $\left(X_{3}\right)$.

$>$ Variabel terikat (dependent variabel), merupakan variabel yang dipengaruhi atau yang menjadi akibat karena adanya variabel bebas. Variabel terikat dalam penelitian ini yaitu kinerja pegawai $(\mathrm{Y})$.

Sugiyono (2018 : 148), mengemukakan bahwa populasi adalah generalisasi yang terdiri atas objek yang mempunyai kualitas dan karakteristik tertentu yang ditetapkan oleh penelitian untuk dipelajari dan kemudian ditarik kesimpulannya. Populasi dalam penelitian ini adalah 57 pegawai sipil dibagian sumda (wakil pimpinan dan pelaksana staf polres yang berada dibawah kapolres) pada Polrestabes Palembang.

Sugiyono (2018 : 149), sampel adalah bagian dari jumlah yang didapatkan dari populasi tersebut. maka teknik pengambilan sampel dalam penelitian ini adalah menggunakan sampling jenuh (sensus). Dengan demikian jumlah populasi dan jumlah sampel sama yaitu 57 pegawai sipil dibagian sumda (wakil pimpinan dan pelaksana staf polres yang berada dibawah kapolres) pada Polrestabes Palembang.

\section{Teknik pengumpulan data}

Sugiyono (2018:224), merupakan langkah paling penting dalam penelitian, karena tujuan dari penelitian itu sendiri adalah untuk memperoleh data. Teknik yang digunakan dalam penelitian dalam pengumpulan data adalah sebagai berikut:

$>$ Observasi, merupakan suatu pengamatan secara langsung ke objek penelitian yang bertujuan memahami masalah dan fenomena yang ada didalam objek penelitian tersebut.

$>$ Kuisioner, merupakan suatu teknik pengumpulan data yang dilakukan dengan cara memberi seperangkat pertanyaan dan pernyataan tertulis kepada responden untuk dijawab. Dalam penelitian ini, angket yang berupa pertanyaan yang digunakan untuk memperoleh data. Kuisioner dalam penelitian ini disusun dalam bentuk pilihan ganda untuk memudahkan responden menjawab pertanyaan.

> Dokumentasi,merupakan sebuah cara yang dilakukan untuk menjadikan dokumen-dokumen dengan menggunakan bukti yang akurat dari pencatatan sumber-sumber informasi khusus dari karangan.

\section{Teknik Analisis Data}

\section{a. Analisis Regresi Linear Sederhana}

Priyatno (2018: 93), Analisis regresi linear sederhana merupakan suatu hubungan secara linear antar suatu variabel independent dengan satu variabel dependen yang digunakan untuk meramalkan suatu nilai variabel dan mengetahui bagaimana pengaruhnya (positif atau negatif). 
Dalam penelitian ini uji analisis regresi linear sederhana digunakan untuk mengetahui pengaruh antar variabel Penempatan $\left(X_{1}\right)$ Beban Kerja $\left(X_{2}\right)$ dan Motivasi Kerja $\left(\mathrm{X}_{3}\right)$, terhadap Kinerja Pegawai $(\mathrm{Y})$.

$\begin{array}{cl}\text { Rumus : } & \mathbf{Y}^{\prime}=\mathbf{a}+\mathbf{b X}+\mathbf{e} \\ \text { Keterangan : } & \\ \mathrm{Y}^{\prime} & \text { : Variabel dependen } \\ \mathrm{a} & \text { : Nilai konstanta } \\ \mathrm{b} & \text { : Koefisien Regresi } \\ \mathrm{X} & \text { : Nilai Variabel Independen } \\ \mathrm{e} & \text { : Error (diasumsikan nilai 0) }\end{array}$

\section{b. Analisis Regresi Linear Berganda}

Priyatno (2018-107), mengemukakan bahwa analisis regrasi linear berganda merupakan analisis yang digunakan untuk menentukan ketepatan prediksi apakah ada hubungan yang kuat antara variabel terikat Penempatan $\left(X_{1}\right)$, Beban Kerja $\left(X_{2}\right)$, dan Motifasi Kerja $\left(\mathrm{X}_{3}\right)$.

Persamaan regrasi linear berganda dirumuskan :

Rumus :

$$
Y=a+b 1 \times 1+B 2 \times 2+B 3 \times 3+e
$$

Keterangan :

$\begin{array}{ll}\text { Y } & \text { : Kinerja Pegawai } \\ \text { a } & \text { : Nilai Konstan } \\ \text { X1 } & \text { : Penempatan } \\ \text { X2 } & \text { : Beban Kerja } \\ \text { X3 } & \text { : Motivasi Kerja } \\ \text { b1 } & \text { : Koefisien Regresi } X_{1} \\ \text { b2 } & \text { : Koefisien Regresi } X_{2} \\ \text { b3 } & \text { : Koefisien Regresi } X_{3} \\ \text { e } & \text { : Error (diamsumsikan nilai 0) }\end{array}$

\section{c. Analisis Koefisien Korelasi Sederhana}

Priyatno (2018:87), menyatahkan bahwa analisis regresi linear berganda merupakan analisis yang digunakan untuk menentukan ketetapan prediksi apakah ada hubungan yang kuat antara variabel terikat terhadap Kinerja Pegawai ( $\mathrm{Y}$ ) dan variabel bebas Penempatan $\left(\mathrm{X}_{1}\right)$, Beban Kerja $\left(\mathrm{X}_{2}\right)$ dan Motivasi Kerja $\left(\mathrm{X}_{3}\right)$.

Persamaan regresi linear berganda dirumuskan:

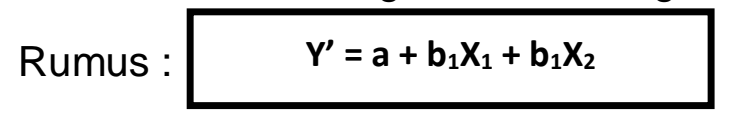

Keterangan :

$\begin{array}{ll}\mathrm{Y} & \text { : Kinerja Pegawai } \\ \mathrm{a} & \text { : Nilai Konstanta } \\ \mathrm{X}_{1} & \text { : Penempatan } \\ \mathrm{X}_{2} & \text { : Beban Kerja } \\ \mathrm{X}_{3} & \text { : Motivasi Kerja } \\ \mathrm{B}_{1} & \text { : Koefisien Regresi } \mathrm{X}_{1}\end{array}$


$\begin{array}{ll}\mathrm{B}_{2} & \text { : Koefisien Regresi } \mathrm{X}_{2} \\ \mathrm{~B}_{3} & \text { : Koefisien Regresi } \mathrm{X}_{3}\end{array}$

\section{d. Analisis Koefisien Determinasi}

Siregar (2014 : 338), merupakan suatu angka yang menyatakan atau yang digunakan untuk mengetahui koefisien dan korelasi yang diberikan oleh variabel atau lebih $X$ (variabel bebas) terhadap $Y$ (variabel terikat). Menghitung koefisien determinasi sebagai berikut :

Rumus :

$$
\mathrm{R}=(\mathbf{r}) 2 \times 100 \%
$$

Keterangan :

R : Koefisien Determinasi

R2 : kuadrat koefisien korelasi

\section{HASIL PENELITIAN}

1) Hasil Uji Validitas

$>$ Variabel Penempatan

Tabel Uji Validitas Variabel Penempatan

\begin{tabular}{|c|c|c|c|c|c|}
\hline No & $\begin{array}{c}\text { Item } \\
\text { pertanyaan }\end{array}$ & rhitung & $r_{\text {tabel }}$ & Kriteria & Keterangan \\
\hline $\begin{array}{c}1 \\
2 \\
3 \\
4 \\
5 \\
6 \\
7 \\
8 \\
9 \\
10\end{array}$ & $\begin{array}{c}\text { Item } 1 \\
\text { Item } 2 \\
\text { Item } 3 \\
\text { Item } 4 \\
\text { Item } 4 \\
\text { Item } 5 \\
\text { Item } 6 \\
\text { Item } 7 \\
\text { Item } 8 \\
\text { Item } 10\end{array}$ & $\begin{array}{l}0,741 \\
0,779 \\
0,763 \\
0,439 \\
0,715 \\
0,687 \\
0,793 \\
0,738 \\
0,676 \\
0,413\end{array}$ & $\begin{array}{l}0,216 \\
0,216 \\
0,216 \\
0,216 \\
0,216 \\
0,216 \\
0,216 \\
0,216 \\
0,216 \\
0,216\end{array}$ & $\begin{array}{l}r_{\text {hitung }}>r_{\text {tabel }} \\
r_{\text {hitung }}>r_{\text {tabel }} \\
r_{\text {hitung }}>r_{\text {tabel }} \\
r_{\text {hitung }}>r_{\text {tabel }} \\
r_{\text {hitung }}>r_{\text {tabel }} \\
r_{\text {hitung }}>r_{\text {tabel }} \\
r_{\text {hitung }}>r_{\text {tabel }} \\
r_{\text {hitung }}>r_{\text {tabel }} \\
r_{\text {hitung }}>r_{\text {tabel }} \\
r_{\text {hitung }}>r_{\text {tabel }}\end{array}$ & $\begin{array}{l}\text { Valid } \\
\text { Valid } \\
\text { Valid } \\
\text { Valid } \\
\text { Valid } \\
\text { Valid } \\
\text { Valid } \\
\text { Valid } \\
\text { Valid } \\
\text { Valid }\end{array}$ \\
\hline
\end{tabular}

Sumber : data primer yang diolah 2021 SPSS 23

Berdasarkan tabel di atas menunjukkan semua butir pertanyaan/pernyataan dari item 1 - 10 pada variabel Penempatan menunjukkan nilai $r_{h i t u n g}>r_{\text {tabel }}$ berarti seluruh butir pertanyaan/pernyataan dapat dikatakan valid. Dari hal ini dapat diartikan butir yang dijadikan indikator variabel Penempatan telah sah untuk dijadikan alat ukur dalam penelitian ini.

\section{$>\quad$ Variabel Beban Kerja}

Tabel Uji Validitas Variabel Beban Kerja

\begin{tabular}{|c|c|c|c|c|c|}
\hline No & $\begin{array}{c}\text { Item } \\
\text { pertanyaan }\end{array}$ & rhitung & $\mathbf{r}_{\text {tabel }}$ & Kriteria & Keterangan \\
\hline 1 & Item 1 & 0,661 & 0,216 & rhitung $>$ rtabel & Valid \\
2 & Item 2 & 0,653 & 0,216 & rhitung $>$ rtabel & Valid \\
3 & Item 3 & 0,734 & 0,216 & rhitung $>$ rtabel & Valid \\
4 & Item 4 & 0,584 & 0,216 & rhitung $>$ rtabel & Valid \\
5 & Item 4 & 0,831 & 0,216 & rhitung $>$ rtabel & Valid \\
6 & Item 5 & 0,744 & 0,216 & rhitung $>$ rtabel & Valid \\
7 & Item 6 & 0,765 & 0,216 & rhitung $>$ rtabel & Valid
\end{tabular}

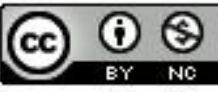




\begin{tabular}{|c|c|c|c|c|c|}
8 & Item 7 & 0,784 & 0,216 & $r_{\text {hitung }}>r_{\text {tabel }}$ & Valid \\
9 & Item 8 & 0,803 & 0,216 & $r_{\text {hitung }}>r_{\text {tabel }}$ & Valid \\
10 & Item 10 & 0,697 & 0,216 & $r_{\text {hitung }}>$ rtabel & Valid \\
\hline
\end{tabular}

Sumber: data primer yang diolah 2021 SPSS 23

Berdasarkan tabel di atas menunjukkan semua butir pertanyaan/pernyataan dari item 1 sampai 10 pada variabel Beban Kerja menunjukkan nilai $r_{\text {hitung }}>r_{\text {tabel }}$ seluruh butir pertanyaan/pernyataan dapat dikatakan valid. Dari hal ini dapat diartikan butir yang dijadikan indikator variabel Beban kerja telah sah untuk dijadikan alat ukur dalam penelitian ini.

Variabel Motivasi Kerja

Tabel Uji Validitas Variabel Motivasi Kerja

\begin{tabular}{|c|c|c|c|c|c|}
\hline No & $\begin{array}{c}\text { Item } \\
\text { pertanyaan }\end{array}$ & r hitung & $\mathbf{r}_{\text {tabel }}$ & Kriteria & Keterangan \\
\hline 1 & Item 1 & 0,871 & 0,216 & rhitung $>$ rtabel & Valid \\
2 & Item 2 & 0,811 & 0,216 & rhitung $>$ rtabel & Valid \\
3 & Item 3 & 0,869 & 0,216 & rhitung $>$ rtabel & Valid \\
4 & Item 4 & 0,785 & 0,216 & rhitung $>$ rtabel & Valid \\
5 & Item 4 & 0,811 & 0,216 & rhitung $>$ rtabel & Valid \\
6 & Item 5 & 0,834 & 0,216 & rhitung $>$ rtabel & Valid \\
7 & Item 6 & 0,819 & 0,216 & rhitung $>$ rtabel & Valid \\
8 & Item 7 & 0,781 & 0,216 & rhitung $>$ rtabel & Valid \\
9 & Item 8 & 0,628 & 0,216 & rhitung $>$ rtabel & Valid \\
10 & Item 10 & 0,611 & 0,216 & rhitung $>$ rtabel & Valid \\
\hline
\end{tabular}

Sumber : data primer yang diolah 2021 SPSS 23

Berdasarkan tabel di atas menunjukkan semua butir pertanyaan/pernyataan dari item 1 sampai 10 pada variabel Motivasi Kerja menunjukkan nilai $r_{\text {hitung }}>r_{\text {tabel }}$ seluruh butir pertanyaan/pernyataan dapat dikatakan valid. Dari hal ini dapat diartikan butir yang dijadikan indikator variabel Motivasi Kerja telah sah untuk dijadikan alat ukur dalam penelitian ini.

$>$ Kinerja Pegawai

Tabel Uji Validitas Variabel Kinerja Pegawai

\begin{tabular}{|c|c|c|c|c|c|}
\hline No & $\begin{array}{c}\text { Item } \\
\text { pertanyaan }\end{array}$ & $\mathbf{r}_{\text {hitung }}$ & $\mathbf{r}_{\text {tabel }}$ & Kriteria & Keterangan \\
\hline $\begin{array}{c}1 \\
2 \\
3 \\
4 \\
5 \\
6 \\
7 \\
8 \\
9 \\
10\end{array}$ & $\begin{array}{l}\text { Item } 1 \\
\text { Item } 2 \\
\text { Item } 3 \\
\text { Item } 4 \\
\text { Item } 4 \\
\text { Item } 5 \\
\text { Item } 6 \\
\text { Item } 7 \\
\text { Item } 8 \\
\text { Item } 10\end{array}$ & $\begin{array}{l}0,664 \\
0,784 \\
0,765 \\
0,739 \\
0,696 \\
0,721 \\
0,514 \\
0,718 \\
0,854 \\
0,734\end{array}$ & $\begin{array}{l}0,216 \\
0,216 \\
0,216 \\
0,216 \\
0,216 \\
0,216 \\
0,216 \\
0,216 \\
0,216 \\
0,216\end{array}$ & $\begin{array}{l}r_{\text {hitung }}>r_{\text {tabel }} \\
r_{\text {hitung }}>r_{\text {tabel }} \\
r_{\text {hitung }}>r_{\text {tabel }} \\
r_{\text {hitung }}>r_{\text {tabel }} \\
r_{\text {hitung }}>r_{\text {tabel }} \\
r_{\text {hitung }}>r_{\text {tabel }} \\
r_{\text {hitung }}>r_{\text {tabel }} \\
r_{\text {hitung }}>r_{\text {tabel }} \\
r_{\text {hitung }}>r_{\text {tabel }} \\
r_{\text {hitut }}\end{array}$ & $\begin{array}{l}\text { Valid } \\
\text { Valid } \\
\text { Valid } \\
\text { Valid } \\
\text { Valid } \\
\text { Valid } \\
\text { Valid } \\
\text { Valid } \\
\text { Valid } \\
\text { Valid }\end{array}$ \\
\hline
\end{tabular}

Sumber : data primer yang diolah 2021 SPSS 23

Berdasarkan tabel di atas menunjukkan semua butir pertanyaan/pernyataan dari item 1 sampai 10 pada variabel Kinerja Pegawai menunjukkan nilai $r_{\text {hitung }}>r_{\text {tabel }}$ berarti seluruh butir pertanyaan/pernyataan dapat dikatakan valid. Dari hal ini dapat 
diartikan butir yang dijadikan indikator variabel Kinerja Pegawai telah sah untuk dijadikan alat ukur dalam penelitian ini.

\section{2) Hasil Uji Reliabilitas}

Tabel Hasil Uji Reliabilitas

\begin{tabular}{|c|c|c|c|}
\hline Variabel & Nilai Reliabilitas & Croncbach Alpha $>\boldsymbol{\alpha}$ & Keterangan \\
\hline $\mathrm{X}_{1}$ & 0,870 & 0,60 & Reliabel \\
$\mathrm{X}_{2}$ & 0,901 & 0,60 & Reliabel \\
$\mathrm{X}_{3}$ & 0,922 & 0,60 & Reliabel \\
$\mathrm{Y}$ & 0,894 & 0,60 & Reliabel \\
\hline
\end{tabular}

Sumber : data primer yang diolah 2021 SPSS 23

Diketahui bahwa nilai koefisien reliabilitas untuk variabel Penempatan $\left(X_{1}\right)$, Beban Kerja $\left(\mathrm{X}_{2}\right)$ dan Motivasi Kerja $\left(\mathrm{X}_{3}\right)$ dan Kinerja Pegawai $(\mathrm{Y})$ Croncbach alpha $>$ 0,60 sehingga semua variabel tersebut dinyatakan reliabel dan dapat digunakan sebagai alat pengumpulan data.

3) Uji Asumsi Klasik

a. Hasil Uji Normalitas

Tabel Hasil Uji Normalitas

\begin{tabular}{|l|c|c|c|}
\hline \multicolumn{1}{|c|}{ Variabel } & Asymp. Sig (2-tailed) & $\mathbf{\alpha = 0 , 0 5}$ & Keterangan \\
\hline $\begin{array}{l}\text { Penempatan, Beban } \\
\text { Kerja dan Motivasi } \\
\text { Kerja terhadap } \\
\text { Kinerja Pegawai. }\end{array}$ & 0,200 & 0,05 & Normal \\
\hline
\end{tabular}

Sumber : data primer yang diolah 2021 SPSS 23

Dapat diketahui bahwa nilai Asymp Sig. (2-tailed) sebesar 0,200. Signifikan lebih dari $0,05(0,200>0,05)$ dengan demikian dapat disimpulkan bahwa hasilnya berdistribusi normal.

b. Hasil Uji Multikolonieritas

Tabel Hasil Uji Multikolonieritas

\begin{tabular}{|c|c|c|c|}
\hline \multirow{2}{*}{ No } & Variabel & \multicolumn{2}{|c|}{ Collinearity statistics } \\
\cline { 2 - 4 } & & Tolerance & VIF \\
\hline 1 & Penempatan $\left(\mathrm{X}_{1}\right)$ & 0,534 & 1,874 \\
2 & Beban Kerja $\left(\mathrm{X}_{2}\right)$ & 0,523 & 1,910 \\
3 & Motivasi Kerja $\left(\mathrm{X}_{3}\right)$ & 0,792 & 1,263 \\
\hline
\end{tabular}

Sumber : data primer yang diolah 2021 SPSS 23

Dapat diketahui nilai tolerance ketiga variabel yaitu variabel Penempatan $\left(\mathrm{X}_{1}\right)$, Beban Kerja $\left(X_{2}\right)$ dan Motivasi Kerja $\left(X_{3}\right)$ dapat disimpulkan bahwa tidak terjadi masalah multikolonieritas.

4) Teknik Analisis Data

a. Analisis Regresi Linear Sederhana

Penempatan $\left(\mathrm{X}_{1}\right)$ terhadap Kinerja Pegawai $(\mathrm{Y})$

hasil menunjukkan rangkuman model regresi linear yang dibentuk berdasarkan hasil regresi linear sederhana untuk variabel Penempatan $\left(\mathrm{X}_{1}\right)$ terhadap Kinerja 
Pegawai $(Y)$ diperoleh koefisien dengan nilai konstanta $=3,958$ dan $B=24,584$ sehingga diperoleh persamaan regresi linear sederhana sebagai berikut :

$$
Y=3,958+24,584 X_{1}
$$

$>\quad$ Beban Kerja $\left(\mathrm{X}_{2}\right)$ terhadap Kinerja Pegawai $(\mathrm{Y})$

menunjukkan rangkuman model regresi linear yang dibentuk berdasarkan hasil regresi linear sederhana untuk variabel Beban Kerja $\left(X_{2}\right)$ terhadap Kinerja Pegawai (Y) diperoleh koefisien dengan nilai konstanta $=3,554$ dan $B=26,932$ sehingga diperoleh persamaan regresi linear sederhana sebagai berikut :

$$
Y=3,554+26,932 X_{2}
$$

$>\quad$ Motivasi Kerja $\left(\mathrm{X}_{3}\right)$ terhadap Kinerja Pegawai $(\mathrm{Y})$

menunjukkan rangkuman model regresi linear yang dibentuk berdasarkan hasil regresi linear sederhana untuk variabel Motivasi Kerja $\left(\mathrm{X}_{3}\right)$ terhadap Kinerja Pegawai (Y) diperoleh koefisien dengan nilai konstanta $=8,524$ dan $B=11,042$ sehingga diperoleh persamaan regresi linear sederhana sebagai berikut :

$$
Y=8,524+11.042 X_{3}
$$

\section{b. Analisis Regresi Linear Berganda}

Tabel Hasil Uji Analisi Regresi Linear Berganda

\begin{tabular}{|c|c|c|}
\hline No & Variabel & Nilai \\
\hline 1 & Konstanta & 8,361 \\
2 & Penempatan & 0,105 \\
3 & Beban Kerja & 0,020 \\
4 & Motivasi Kerja & 0,601 \\
\hline
\end{tabular}

Sumber : data primer yang diolah 2021 SPSS 23

hasil nilai persamaan regresi linear berganda adalah sebagai berikut :

$Y=a+b_{1} X_{1}+b_{2} X_{2}+b_{3} X_{3}+e$

$Y=8,361+0,105 X_{1}+0,020 X_{2}+0,601 X_{3}+e$

hasil persamaan regresi linear berganda, maka dapat di analisis sebagai berikut :

1) 8,361, artinya jika Penempatan 0, Beban Kerja 0 dan Motivasi Kerja, ,maka Kinerja Pegawai akan meningkat adalah 8,361.

2) 0,105 , artinya jika Penempatan meningkat sebesar satu tingkatan, maka Kinerja Pegawai akan meningkat sebesar 0,105 tingkatan.

3) 0,020, artinya jika Beban Kerja meningkat sebesar satu tingkatan, maka Kinerja Pegawai akan meningkat sebesar 0,020 tingkatan.

4) 0,601 , artinya jika Motivasi Kerja meningkat sebesar satu tingkatan, maka Kinerja Pegawai akan meningkat sebesar 0,601 tingkatan.

\section{c. Hasil Koefisien Korelasi}

Tabel Koefisien Korelasi

\begin{tabular}{|c|c|c|c|}
\hline Variabel & Person Correlation & Signifikan & Tingkat Hubungan \\
\hline Penempatan & 0,776 & 0,602 & Korelasi Kuat \\
Beban Kerja & & & \\
Motivasi Kerja & & & \\
Kinerja Pegawai & & & \\
\hline
\end{tabular}

Sumber : data primer yang diolah 2021 SPSS 23 
dilihat bahwa nilai $r$ sebesar 0,776 berarti berada pada rentang $0,60-0,80$. Hal ini mununjukkan bahwa derajat hubungan antara variabel Penempatan $\left(X_{1}\right)$, Beban Kerja $\left(\mathrm{X}_{2}\right)$ dan Motivasi Kerja $\left(\mathrm{X}_{3}\right)$ terhadap Kinerja Pegawai $(\mathrm{Y})$ adalah kolerasi kuat.

\section{d. Hasil Koefisien Determinasi}

Tabel Hasil Koefisien Determinasi Variabel Penempatan $\left(\mathbf{X}_{1}\right)$, Beban $\operatorname{Kerja}\left(\mathbf{X}_{2}\right)$ dan Motivasi Kerja $\left(X_{3}\right)$ terhadap Kinerja Pegawai $(Y)$ Model Summary

\begin{tabular}{|c|c|c|c|c|}
\hline Model 1 & R & R Square & $\begin{array}{l}\text { Adjusted R } \\
\text { Square }\end{array}$ & $\begin{array}{l}\text { Std. Error of the } \\
\text { Estimate }\end{array}$ \\
\hline $\begin{array}{c}\text { Penempatan } \\
\text { Beban Kerja dan } \\
\text { Motivasi Kerja } \\
\text { Terhadap Kinerja } \\
\text { Pegawai }\end{array}$ & 0,776 & 0,602 & 0,579 & 4,048 \\
\hline
\end{tabular}

Sumber : data primer yang diolah 2021 SPSS 23

bahwa besarnya $\mathrm{R}$ Square adalah 0,601 atau $60,2 \%$. Artinya kontribusi pengaruh variabel Penempatan $\left(\mathrm{X}_{1}\right)$, Beban Kerja $\left(\mathrm{X}_{2}\right)$ dan Motivasi Kerja $\left(\mathrm{X}_{3}\right)$ terhadap Kinerja Pegawai $(Y)$ adalah sebesar $60,2 \%$ sedangkan sisanya sebesar $(100 \%-60,2 \%)=$ $39,8 \%$ dipengaruhi oleh faktor-faktor lain yang tidak termasuk dalam penelitian ini.

\section{5) Hasil Pengujian Hipotesis}

1. Hasil Uji t

> Penempatan $\left(\mathrm{X}_{1}\right)$ terhadap Kinerja Pegawai $(\mathrm{Y})$

Tabel Uji t Penempatan $\left(X_{1}\right)$ terhadap Kinerja Pegawai $(Y)$

\begin{tabular}{|l|c|c|c|c|}
\hline Variabel & $\mathbf{T}$ & Signifikan & $\mathbf{\alpha = 0 , 0 5}$ & Keterangan \\
\hline Penempatan & 7,269 & 0,000 & 0,05 & Signifikan \\
\hline
\end{tabular}

Sumber: data primer yang diolah 2021 SPSS 23

hasil menunjukkan nilai signifikan antara variabel Penempatan $\left(X_{1}\right)$ terhadap (Y) sebesar $0,000<0,05$ artinya $H_{0}$ ditolak $\mathrm{Ha}$ diterima, sehingga dapat disimpulkan bahwa terdapat pengaruh signifikan antara variabel Penempatan $\left(\mathrm{X}_{1}\right)$ terhadap $(\mathrm{Y})$.

$>$ Beban Kerja $\left(\mathrm{X}_{2}\right)$ Terhadap Kinerja Pegawai $(\mathrm{Y})$

Tabel Uji t Beban Kerja $\left(\mathrm{X}_{2}\right)$ Terhadap Kinerja Pegawai $(\mathrm{Y})$

\begin{tabular}{|l|c|c|c|c|}
\hline Variabel & $\mathbf{T}$ & Signifikan & $\boldsymbol{\alpha}=\mathbf{0 , 0 5}$ & Keterangan \\
\hline Beban Kerja & 8,665 & 0,001 & 0,05 & Signifikan \\
\hline
\end{tabular}

Sumber: data primer yang diolah 2021 SPSS 23

hasil menunjukkan nilai signifikan antara variabel Beban $\operatorname{Kerja}\left(\mathrm{X}_{2}\right)$ terhadap Kinerja Pegawai $(Y)$ sebesar $0,000<0,05$ artinya $\mathrm{H}_{0}$ ditolak Ha diterima, sehingga dapat disimpulkan bahwa terdapat pengaruh signifikan antara variabel $\operatorname{Beban} \operatorname{Kerja}\left(\mathrm{X}_{2}\right)$ terhadap Kinerja Pegawai $(\mathrm{Y})$. 
$>\quad$ Motivai Kerja $\left(\mathrm{X}_{3}\right)$ Terhadap Kinerja Pegawai $(\mathrm{Y})$

Tabel Uji t Motivai Kerja $\left(X_{3}\right)$ Terhadap Kinerja Pegawai (Y)

\begin{tabular}{|l|c|c|c|c|}
\hline Variabel & $\mathbf{T}$ & Signifikan & $\boldsymbol{\alpha}=\mathbf{0 , 0 5}$ & Keterangan \\
\hline Motivasi Kerja & 3,484 & 0,000 & 0,05 & Signifikan \\
\hline
\end{tabular}

Sumber: data primer yang diolah 2021 SPSS 23

hasil menunjukkan nilai signifikan antara variabel Motivasi $\operatorname{Kerja}\left(\mathrm{X}_{3}\right)$ terhadap Kinerja Pegawai $(\mathrm{Y})$ sebesar $0,000<0,05$ artinya $\mathrm{H}_{0}$ ditolak $\mathrm{Ha}$ diterima, sehingga dapat disimpulkan bahwa terdapat pengaruh signifikan antara variabel Motivasi $\operatorname{Kerja}\left(\mathrm{X}_{3}\right)$ terhadap Kinerja Pegawai( $\left.\mathrm{Y}\right)$.

\section{Hasil Uji F}

Tabel Hasil Pengujian Secara Simultan Dengan Uji F Anova

\begin{tabular}{|l|c|c|c|c|}
\hline Variabel & $\mathbf{F}$ & Signifikan & $\boldsymbol{\alpha}=\mathbf{0 , 0 5}$ & Keterangan \\
\hline $\begin{array}{l}\text { Penempatan } \\
\text { Beban Kerja dan } \\
\text { Motivasi Kerja } \\
\text { Terhadap Kinerja } \\
\text { Pegawai }\end{array}$ & 26,694 & 0,000 & 0,05 & Signifikan \\
\hline
\end{tabular}

Sumber: data primer yang diolah 2021 SPSS 23

Berdasarkan Uji F menunjukkan nilai signifikan sebesar 0,000 $<0,05$. Artinya $\mathrm{H}_{0}$ ditolak dan $\mathrm{Ha}$ diterima.sehingga dapat disimpulkan bahwa terdapat pengaruh yang signifikan antara Penempatan $\left(X_{1}\right)$,Beban Kerja $\left(X_{2}\right)$ dan Motivasi Kerja $\left(\mathrm{X}_{3}\right)$ terhadap Kinerja Pegawai $(\mathrm{Y})$ pada Polrestabes Palembang.

\section{E. PEMBAHASAN}

1) Pengaruh Penempatan $\left(X_{1}\right)$ Terhadap Kinerja Pegawai $(Y)$

Berdasarkan hasil uji validitas menunjukkan semua item pertanyaan yang digunakan dalam variabel Penempatan $\left(X_{1}\right)$ dalam penelitian ini mempunyai nilai signifikan $0,000<0,05$ untuk semua sampe 57 responden. Dari hasil tersebut menunjukkan bahwa semua pertanyaan/pernyataan adalah valid.

Dari hasil reliabilitas menunjukkan Penempatan $\left(X_{1}\right)$ diperoleh nilai Cronbanch's Alpha sebesar $0,870>0,60$ maka dapat disimpulkan bahwa seluruh item perrtanyaan/pernyataan adalah reliabel.

Dari hasil regresi linear sederhana diperoleh hasil koefisien regresi untuk Penempatan $\left(X_{1}\right)$ sebesar 24,584 serta konstanta 3,958 maka persamaan regresi sederhana antara Penempatan $\left(\mathrm{X}_{1}\right)$ terhadap Kinerja Pegawai $(\mathrm{Y})$ adalah $\mathrm{Y}=3,958$ $+24,584 X_{1}$.

Dari hasil pengujian hipotesis (uji t) menunjukkan nilai signifikan antara variabel Penempatan $\left(\mathrm{X}_{1}\right)$ terhadap Kinerja Pegawai $(\mathrm{Y})$ sebesar $0,000<0,05$ yang artinya secara parsial ada pengaruh yang signifikan antara Penempatan $\mathrm{X}_{1}$ terhadap Kinerja Pegawai Y.

\section{2) Pengaruh Beban Kerja ( $\left.X_{1}\right)$ Terhadap Kinerja Pegawai ( $Y$ )}

Berdasarkan hasil uji validitas menunjukkan semua item pertanyaan/pernyataan yang digunakan dalam variabel Beban Kerja $\left(X_{2}\right)$ dalam penelitian ini mempunyai 
nilai signifikan 0,000 $<0,05$ untuk semua sampel sebanyak 57 responden. Dari hasil tersebut menunjukkan bahwa semua pertanyaan/pernyataan adalah valid.

Dari hasil reliabilitas menunjukkan bahwa Beban Kerja $\left(X_{2}\right)$ diperoleh nilai Cronbanch's Alpha sebesar 0,901 > 0,60 maka dapat disimpulkan bahwa seluruh item pertanyaan/pernyataan adalah reliabel.

Hasil regresi linear sederhana diperoleh hasil koefisien regresi untuk Beban Kerja $\left(X_{2}\right)$ sebesar 26,932 serta konstanta 3,554 maka persamaan regresi sederhana antara variabel Beban Kerja $\left(\mathrm{X}_{2}\right)$ terhadap Kinerja Pegawai $(\mathrm{Y})$ adalah $\mathrm{Y}=3,554+$ $26,932 X_{2}$.

Berdasarkan hasil pengujian hipotesis (uji t) menunjukkan nilai signifikan antara variabel Beban Kerja $\left(\mathrm{X}_{2}\right)$ terhadap Kinerja Pegawai $(\mathrm{Y})$ sebesar $0.000<0,05$ yang artinya secara parsial ada pengaruh yang signifikan antara Beban Kerja $\left(\mathrm{X}_{2}\right)$ terhadap Kinerja Pegawai (Y).

\section{3) Pengaruh Motivasi Kerja $\left(\mathrm{X}_{3}\right)$ Terhadap Kinerja Pegawai ( $\mathrm{Y}$ )}

Berdasarkan hasil uji validitas menunjukkan semua item pertanyaan/pernyataan yang digunakan dalam variabel Motivasi Kerja $\left(X_{3}\right)$ dalam penelitian ini mempunyai nilai signifikan 0,000 $<0,05$ untuk semua sampel 57 responden. Dari hasil tersebut menunjukkan bahwa semua pertanyaan/pernyataan adalah valid.

Dari hasil reliabilitas menunjukkan bahwa Motivasi Kerja $\left(\mathrm{X}_{3}\right)$ diperoleh nilai Cronbanch's Alpha sebesar 0,922 > 0,60 maka dapat disimpulkan bahwa seluruh item pertanyaan/pernyataan adalah reliabel.

Hasil regresi linear sederhana diperoleh hasil koefisien regresi untuk Motivasi $\operatorname{Kerja}\left(\mathrm{X}_{3}\right)$ sebesar 11,042 serta konstanta 8,524 maka persamaan regresi sederhana antara variabel Beban Kerja $\left(\mathrm{X}_{2}\right)$ terhadap Kinerja Pegawai $(\mathrm{Y})$ adalah $\mathrm{Y}=8,524+$ $11,042 X_{3}$

Berdasarkan hasil pengujian hipotesis (uji t) menunjukkan nilai signifikan antara variabel Motivasi Kerja $\left(\mathrm{X}_{3}\right)$ terhadap Kinerja Pegawai $(\mathrm{Y})$ sebesar $0.000<0,05$ yang artinya secara parsial ada pengaruh yang signifikan antara Motivasi Kerja $\left(\mathrm{X}_{3}\right)$ terhadap Kinerja Pegawai (Y).

\section{4) Pengaruh Penempatan $\left(X_{1}\right)$, Beban Kerja $\left(X_{2}\right)$ Dan Motivasi Kerja $\left(X_{3}\right)$ Terhadap Kinerja Pegawai (Y)}

Pada uji normalitas masing-masing variabel yang terdiri dari Penempatan $\left(X_{1}\right)$, Beban Kerja $\left(\mathrm{X}_{2}\right)$ dan Motivasi Kerja $\left(\mathrm{X}_{3}\right)$ terhadap Kinerja Pegawai $(\mathrm{Y})$ memperoleh Sig (2-tailed) lebih besar dari 0,05 jadi dapat disimpulkan bahwa data pada penelitian ini berdistribusikan Normal.

Dari hasil Multikolonieritas dapat diketahui bahwa nilai tolerance dari ketiga variabel Penempatan $\left(\mathrm{X}_{1}\right)$, Beban Kerja $\left(\mathrm{X}_{2}\right)$ dan Motivasi Kerja $\left(\mathrm{X}_{3}\right)$ dapat disimpulkan bahwa tidak terjadi masalah multikolonieritas.

Dari hasil heteroskedatisitas Penempatan $\left(X_{1}\right)$ menghasilkan nilai signifikan 0,534 > 0,05 Beban Kerja $\left(X_{2}\right)$ menghasilkan nilai signifikan 0,542 dan Motivasi Kerja menghasilkan nilai signifikan 0,671 dengan dapat disimpulkan bahwa tidak terjadi heteroskedatisitas pada model regresi.

Dari hasil output koefisien kolerasi diperoleh nilai kolerasi ( $r$ ) sebesar 0,776 berarti berada pada rentang 0,60-0,80. Hal ini menunjukkan bahwa kolerasi antara Penempatan $\left(\mathrm{X}_{1}\right)$, Beban Kerja $\left(\mathrm{X}_{2}\right)$ dan Motivasi Kerja $\left(\mathrm{X}_{3}\right)$ terhadap Kinerja Pegawai (Y) korelasi kuat.

Dari hasil determinasi diperoleh nilai $R$ Square $\left(R^{2}\right)$ sebesar 0,601 atau 60,1\%. Artinya kontribusi sumbangan pengaruh variabel Penempata $\left(X_{1}\right)$, Beban Kerja $\left(X_{2}\right)$ 
dan Motivasi Kerja $\left(\mathrm{X}_{3}\right)$ terhadap Kinerja Pegawai $(\mathrm{Y})$ adalah sebesar 0,601 sisanya $(100 \%-60,1 \%)=39,8 \%$ diperoleh oleh faktor-faktor lain yang tidak termasuk dalam penelitian ini.

Dari hasil pengujian hipotesis uji t secara parsial antara variabel apakah (X) berpengaruh terhadap $(Y)$ maka dibandingkan dengan menggunakan t-tabel. Diketahui nilai signifikan untuk pengaruh Penempatan $\left(X_{1}\right)$ terhadap Kinerja Pegawai (Y) sebesar 0,000 $<0,05$. sehingga disimpulkan bahwa $\mathrm{H}_{1}$ diterima yang berarti terdapat pengaruh $\mathrm{X}_{1}$ terhadap $\mathrm{Y}$. nilai signifikan Beban Kerja $\left(\mathrm{X}_{2}\right)$ terhadap Kinerja Pegawai $(Y)$ adalah sebesar $0,000<0,05$. Sehingga dapat disimpulkan bahwa $\mathrm{H}_{2}$ diterima yang berarti terdapat pengaruh antara variabel Beban Kerja $\left(\mathrm{X}_{2}\right)$ terhadap Kinerja Pegawai $(Y)$. dan nilai signifikan Motivasi Kerja $\left(X_{3}\right)$ terhadap Kinerja Pegawai $(Y)$ adalah sebesar 0,000 $<0,05$. Sehingga dapat disimpulkan bahwa $\mathrm{H}_{3}$ diterima yang berarti terdapat pengaruh antara variabel Motivasi Kerja $\left(X_{3}\right)$ terhadap Kinerja Pegawai (Y).

Dari hasil pengujian uji $\mathrm{F}$ secara simultan atau bersama-sama antara variabel Penempatan $\left(X_{1}\right)$, Beban Kerja $\left(X_{2}\right)$ dan Motivasi Kerja $\left(X_{3}\right)$ terhadap Kinerja Pegawai $(Y)$ diperoleh nilai signifikan $0,000<0,05$ maka hipotesis nol $\left(\mathrm{H}_{0}\right)$ ditolak dan hipotesis alternative $\left(\mathrm{H}_{\mathrm{a}}\right)$ diterima. Sehingga dapat disimpulkan bahwa terdapat pengaruh yang signifikan antara Penempatan $\left(\mathrm{X}_{1}\right)$, Beban Kerja $\left(\mathrm{X}_{2}\right)$ dan Motivasi Kerja $\left(\mathrm{X}_{3}\right)$ terhadap Kinerja Pegawai $(\mathrm{Y})$ pada Polrestabes Palembang.

\section{F. KESIMPULAN DAN SARAN}

1. Kesimpulan

Berdasarkan hasil penelitian pembahasan yang telah diuraikan pada bab sebelumnya, dapat disimpulkan sebagai berikut :

a) Berdasarkan hasil pengujian hipotesis antara variabel Penempatan $\left(\mathrm{X}_{1}\right)$ terhadap Kinerja Pegawai $(Y)$ diperoleh nilai sig $0,000<0,05$. Maka dapat disimpulkan bahwa secara parsial ada pengaruh antara variabel Penempatan terhadap Kinerja Pegawai pada Polrestabes Palembang

b) Berdasarkan hasil pengujian hipotesis antara variabel Beban Kerja $\left(\mathrm{X}_{2}\right)$ terhadap Kinerja Pegawai (Y) diperoleh nilai sig 0,001 $<0,05$ maka dapat disimpulkan bahwa secara parsial ada pengaruh antara variabel beban kerja terhadap kinerja pegawai pada Polrestabes Palembang.

c) Berdasarkan hasil pengujian hipotesis antara variabel Motivasi Kerja $\left(\mathrm{X}_{3}\right)$ terhadap Kinerja Pegawai $(Y)$ diperoleh nilai sig 0,000 $<0,05$ maka dapat disimpulkan bahwa secara parsial ada pengaruh antara variabel motivasi kerja terhadap kinerja pegawai pada Polrestabes Palembang.

d) Berdasarkan pengujian hipotesis secara bersama-sama antara variabel penempatan $\left(\mathrm{X}_{1}\right)$, Beban Kerja $\left(\mathrm{X}_{2}\right)$ dan Motivasi Kerja $\left(\mathrm{X}_{3}\right)$ terhadap Kinerja Pegawai $(Y)$ diperoleh nilai sig $0,000<0,05$. Maka hipotesis alternativ $(\mathrm{Ha})$ diterima (Ho) ditolak. Hal ini menunjukkan bahwa ada pengaruh signifikan antara Penempatan, Beban Kerja dan Motivasi Kerja Terhadap Kinerja Pegawai pada Polrestabes Palembang.

\section{Saran}

Berdasarkan kesimpulan yang telah diuraikan, maka saran yang dapat peneliti sampaikan sebagai berikut : 
a) Supaya bisa meningkatkan kinerja pegawai, Polrestabes Palembang diharapkan dapat menciptakan suasana yang menyenangkan, sehingga pegawai dapat bekerja dengan baik dan mendapatkan hasil kerja sesuai dengan yang diharapkan.

b) Untuk meningkatkan motivasi kerja pegawai supaya ada pelatihan-pelatihan yang dibutuhkan oleh pegawai dan membuat pegawai semakin semangat untuk bekerja dengan adanya pelatihan itu.

c) Penempatan dan Beban Kerja, pada Penempatan diPolrestabes Palembang supaya bisa diteliti lagi untuk penempatan pegawainya karna ada pegawai yang tidak sesuai dengan bidangnya,karena beban kerja di Polrestabes Palembang banyak yang tidak sesuai dengan jam kerja dan membuat pegawai menjadi kelelahan dalam mengerjakan pekerjaannya dan untuk lebih baiknya jam kerja pegawai ditambah waktunya supaya bisa bekerja dengan lebih baik lagi.

d) Kepada pihak yang ingin melakukan penelitian selanjutnya, agar disarankan untuk meneliti variabel yang lain untuk menghindari adanya aktivitas plagiarism yang tentu saja melanggar etika penulis skripsi.

\section{DAFTAR PUSTAKA}

Busro, M. (2018). Teori-Teori Sumber Daya Manusia. jakarta: Prenamedia Group.

Hasibuan, M. S. (2015). Organisasi Dan Motivasi . Jakarta: PT Bumi Aksara.

Hannani, A. (2016). Analisis Fitokimia. Jakarta: Kedokteran EGC.

Mondy. (2015). manajemen sumber daya manusia. jakarta: erlangga.

Priyatno, D. (2018). SPSS Panduan Mudah Olah Data Bagi Mahasiswa Dan Umum. Yogyakarta: Andi.

Sinambela, L. P. (2017). Manajemen Sumber Daya Manusia. Jakarta: PT Bumi Aksara.

Siregar, S. (2014). Metode Penelitian Kuantitatif. Jakarta: PT. Fajar Interpratama Mandiri.

Sugiyono. (2018). Metode Penelitian Kuantitatif Kualitatif Dan R\&D . Bandung: Alfabeta.

Suparyadi. (2015). Manajemen Sumber Daya Manusia. Yogyakarta: Andi.

Tohardi, A. (2016). Pemahaman Praktis Manajemen Sumber Daya Manusis. Bandung: CV Mandar Maju.

Tarwaka. (2017). dasar-dasar pengetahuan ergonomi dan aplikasi ditempat kerja . surakarta: harapan press.

Wibowo. (2014). Manajemen Kinerja. Jakarta: PT. Raja Gravindo Persada. 